\title{
Perinatal Feedings Adversely Affect Lipogenic Activities but Not Glucose Handling in Adult Rats
}

\author{
LINO C. BALONAN AND HWAI-PING SHENG
}

Department of Physiology, The University of Hong Kong, Hong Kong SAR, China

\begin{abstract}
ABST
The long-term effects of early under- and overfeeding on
glucose metabolism and fat cell lipogenesis were studied. New-
born rats were reared in litter sizes of four, 10, and 16 pups. The
amount of milk intake per pup varied inversely with litter sizes.
A subgroup of pups from each group was studied at age 20 d,
whereas another subgroup was weaned to an ad libitum feeding
of standard rat chow and studied at 12 wk of age. There were no
differences among groups in food intake on the basis of per gram
body weight. Overfeeding during suckling resulted in fatter rats
at weaning and in the adults. The higher fat contents in the
adipose tissues and carcasses were associated with higher fatty
acid synthase and lipogenic activities in the adipose tissues at
weaning and 12 wk of age. Differences in plasma insulin and
glucose levels among groups were observed only in the 20-d-old
\end{abstract}
Persistent impairment of insulin secretion and glucose tolerance has been observed after refeeding in malnourished infants (1) and in rats subjected to protein-calorie (2) and protein (3) malnutrition. On the other hand, overfeeding rats during the suckling period was associated with hyperinsulinemia in infancy and impaired glucose tolerance and obesity in the adult (4). Enlarged adipocytes biopsied from obese adult humans showed decreased sensitivity to insulin action (5), an effect proposed as one of the factors influencing insulin secretion (6).

In rats, the level of FAS, an enzyme that catalyzes de novo synthesis of fatty acid, declines during fasting and increases during refeeding. These changes in FAS levels have been attributed to an insulin-stimulated transcription of FAS in the liver and adipose tissues (7), a proposal supported by the findings that incubation of human adipocytes with insulin increases FAS activity (8). It has also been reported that the expression of FAS in mice can be altered by dietary composition (9). This may explain the increase in the mRNA con-

Received December 8, 1999; accepted June 1, 2000.

Correspondence and reprint requests: H.P. Sheng, Ph.D., Department of Physiology, Faculty of Medicine, The University of Hong Kong, 5 Sassoon Road, Hong Kong SAR, China.

Funded by The University of Hong Kong CRCG grant and supported in part by RGC Competitive Earmarked Research Grant. rats: basal insulin and glucose levels and 30-min postglucose insulin levels were highest in the overnourished and lowest in the undernourished rats. However, by 12 wk of age, there were no significant differences among groups in their basal insulin and glucose levels and after an oral dose of glucose. Our results suggest that overfeeding or underfeeding during the suckling period affects the glucose-insulin axis only temporarily and not permanently, but early overfeeding permanently enhances fatty acid synthase and lipogenic activities in adipose tissues, resulting in fatter adult rats. (Pediatr Res 48: 668-673, 2000)
FAS, fatty acid synthase
Abbreviations
RSA, relative specific activity

centrations and activities of lipogenic enzymes such as FAS and acetyl CoA-carboxylase in rats during weaning $(10,11)$.

In experimental animals, it has been shown that either underfeeding or overfeeding during early infancy confers a lasting effect on body fat content (12). However, whether this is a direct consequence of changes in insulin levels and lipogenic enzyme activities is not known. We postulate that early postnatal nutrition imparts changes in body fat deposition in the adult as a consequence of permanent alterations in the metabolic pathway of fat synthesis and that these changes are a result of early programming of FAS activities induced by changes in the glucose-insulin axis during the suckling period. The objectives of the present study are to investigate the effects of different planes of nutrition during suckling on adiposity and changes in secretory insulin response and lipogenic enzyme activities at weaning and at $12 \mathrm{wk}$ of age after the rats were weaned to a standard diet ad libitum.

\section{METHODS}

Experimental design. Timed pregnant female SpragueDawley rats weighing $300 \pm 20 \mathrm{~g}$ were housed in individual stainless steel wire cages in a room on a $12: 12$-h light/dark cycle with the room temperature controlled at $22 \pm 1^{\circ} \mathrm{C}$. The animals had free access to commercial rat chow (Laboratory Autoclavable Rodent Diet 5010, PMI Food Inc., MO, U.S.A.) 
and water. On the day of birth, designated as day 0, pups from all the dams were pooled, weighed, and randomly assigned to suckle in litters of four (group S), 10 (group M), and 16 pups (group L) so as to vary their milk intake and thus their growth rates. A subgroup of pups was studied at weaning ( $20 \mathrm{~d}$ of age), and another subgroup was weaned to rat chow ad libitum until 12 wk of age. The following parameters were studied at ages $20 \mathrm{~d}$ and 12 wk: 1) basal plasma insulin and glucose levels and basal FAS and lipogenic activities of retroperitoneal fat pads, 2) plasma insulin and glucose levels at 15,30,45, and $60 \mathrm{~min}$ after an oral glucose load of $3 \mathrm{~g} / \mathrm{kg}$ body weight, 3) FAS and lipogenic activities of retroperitoneal fat pads at $60 \mathrm{~min}$ after the glucose load, and 4) fat contents of retroperitoneal fat pads and eviscerated carcass. Growth rates were monitored by serial weighing twice a week from birth until 12 wk of age, and food intakes were recorded twice a week after weaning.

On the day of study at approximately $1030 \mathrm{~h}$, feedings were withheld from 32 litters of rats from each group for $4 \mathrm{~h}$ before they were anesthetized with pentobarbital sodium $(30 \mathrm{mg} / \mathrm{kg}$ body weight) intraperitoneally. Pups were kept warm in plastic cages under a lamp between the time of anesthesia and study. For the study of glucose tolerance, 1 to $2 \mathrm{~mL}$ of blood was withdrawn by cardiac puncture from eight litters of rats from each group for the analyses of baseline levels of plasma insulin and glucose. Another eight litters of rats from each group were given a dose of glucose ( $3 \mathrm{~g} / \mathrm{kg}$ body weight) via gastric tubes, and 1 to $2 \mathrm{~mL}$ of blood was collected at either $15,30,45$, or 60 min after the oral glucose for the assay of plasma levels of insulin and glucose. All plasma samples were stored at $-72^{\circ} \mathrm{C}$ until they were analyzed. After blood collections, the rats were killed by an intraperitoneal overdose of pentobarbital sodium, and bilateral retroperitoneal fat pads were dissected out. Some of the samples were frozen at $-4^{\circ} \mathrm{C}$ for later analysis of their fat content, and others were frozen rapidly in liquid nitrogen and stored at $-72^{\circ} \mathrm{C}$ for later analysis of FAS activities. Each carcass was emptied of its visceral contents, weighed, and frozen for later analysis of its fat content.

Baseline lipogenic activities in the retroperitoneal fat pads were studied in another eight litters of pups from each group after the 4-h fast, whereas another eight litters were studied at $60 \mathrm{~min}$ after a dose of glucose ( $3 \mathrm{~g} / \mathrm{kg}$ body weight). Lipogenic activities were measured by using a tritium incorporation method in which a dose of tritium oxide was injected intraperitoneally (13). All blood and fat pads collected were stored at $-72^{\circ} \mathrm{C}$ until they were analyzed. Plasma samples were determined for their radioactivity, and fat pads were analyzed for the tritium incorporated into their fatty acids. The protocol was approved by the Committee on the Use of Live Animals for Teaching and Research of the University of Hong Kong.

Fat content. Fat contents of the retroperitoneal fat pads and eviscerated carcasses were measured, with some modification, by the method of Sheng et al. (14). Briefly, fat pads and carcasses were weighed in separate containers and then dried to constant weights in an oven at $95^{\circ} \mathrm{C}$. The dried carcass was ground to a fine powder, and a weighed sample was placed in a preweighed vial. Ether was added in the proportion of 10 parts of ether to one part of sample. The ether was decanted the next day, and the procedure was repeated twice before the sample was dried and weighed. This procedure was repeated, and fat extraction was considered complete when subsequent fat-free dried weight remained constant. The difference in dried weights before and after ether extraction represents the weight of fat in the sample.

Plasma insulin levels. Baseline and postglucose plasma insulin levels were analyzed by an RIA method using a ${ }^{125} \mathrm{I}-$ insulin RIA kit (DiaSorin Inc., MN, U.S.A.). Response of pancreatic secretion of insulin to a glucose load was calculated from the area under the curve of the plasma insulin levels over a 60 -min period.

Plasma glucose levels. Plasma glucose levels were determined by a glucose oxidase method using a glucose diagnostic kit (Sigma Chemical Co. cat. 510-A, MO, U.S.A.). Calculation of plasma glucose levels over the 60 -min period after a glucose load was similar to that of plasma insulin: the area under the curve of plasma glucose over a 60 -min period was computed.

FAS activity. FAS activity in the fat pads was measured by a spectrophotometric method (15). Briefly, an aliquot of the frozen fat pad was thawed and homogenized in 3 vol of a cold solution containing $0.15 \mathrm{M} \mathrm{KPO}_{4}$ and $1 \mathrm{mM} \mathrm{DTT}$, $\mathrm{pH} 6.8$, in a motor-driven Teflon pestle. Homogenates were kept cold in ice and then centrifuged at $4{ }^{\circ} \mathrm{C}$ at $20,000 \times g$ for $20 \mathrm{~min}$. The upper fat layer was removed, and the infranatant, which contained the FAS, was aspirated and centrifuged again. The infranatant $(0.3 \mathrm{~mL})$ was used for assay in $0.8 \mathrm{~mL}$ of assay cocktail (0.15 $\mathrm{M} \mathrm{KPO}_{4}, 1 \mathrm{mM}$ DTT, $1 \mathrm{mM}$ EDTA, $0.15 \mathrm{mM}$ NADPH, $40 \mu \mathrm{M}$ acetyl-CoA). The reaction was initiated by the addition of $0.1 \mathrm{~mL}$ of $0.1 \mathrm{mM}$ malonyl-CoA, and the oxidation of NADPH followed at $340 \mathrm{~nm}$. The OD was recorded continuously for 2 to $5 \mathrm{~min}$. The linear portion of the curve was used to determine maximal activity. Correction was made for the rate of NADPH oxidation in the absence of malonyl-CoA. The enzyme activity was expressed in nanomoles of palmitate synthesized per milligram of protein per minute. Soluble protein was assayed by using the microKjeldahl method (Kjeltec 1030 Analyzer, Tecator, Sweden).

Lipogenesis. Lipogenic activities of fat pads were measured by tritium incorporation by using the method, with some modification, of Jungas (16). Tritium oxide (Amersham, NJ, U.S.A.) was injected intraperitoneally at a dose between 100 $\mu \mathrm{Ci} / 100 \mathrm{~g}$ body weight and $1 \mathrm{mCi} / 100 \mathrm{~g}$ body weight, depending on the weight of the animals. Tissue samples of known weights were saponified by homogenization with ethanolic $\mathrm{NaOH}(6: 1)$ and refluxed at $95^{\circ} \mathrm{C}$ for $4 \mathrm{~h}$ on a heating block. Samples were cooled to room temperature, and $1 \mathrm{~mL}$ of deionized water was added to each sample. Nonfatty acid lipids were removed with ether, and the residues were acidified with $\mathrm{HCl}$ and extracted again with ether. The extractants that contained the fatty acids were collected into scintillation vials and dried overnight. Scintillation cocktail was added to each sample, and its radioactivity (cpm) was counted in a liquid scintillation counter (Beckman LS 6500 Liquid Scintillation System, CA, U.S.A.).

Incorporation of ${ }^{3} \mathrm{H}$-fatty acid into tissues, expressed as total activity per gram of tissue (17), was calculated by multiplying the number of millimoles of fatty acids in the tissues by the RSA of fatty acids. The number of millimoles of fatty acids 
was determined from titration of fatty acid extracts with $0.1 \mathrm{~N}$ $\mathrm{NaOH}$ of a known weight of tissue samples and expressed as $\mathrm{mmol} / \mathrm{g}$ tissue. The RSA of fatty acids was calculated from the specific activity of fatty acids in plasma divided by specific activity of plasma water.

Data analysis. Data from the male and female pups were analyzed separately, and only data for the male pups are presented. As individual pups within a litter cannot be regarded as independent statistically, data from male pups within each litter were pooled and averaged, and the litter mean is considered as $n=1$. Therefore, in all statistical analyses, $n$ equals the number of litters. One-way ANOVA was used to test for differences among groups. When significant differences among groups were found, a pairwise comparison analysis using Student-Newman-Keuls test was done. Level of significance was set at $p<0.05$. Data are presented as mean $\pm 1 \mathrm{SD}$. All analyses were performed with SigmaStat statistical software (Jandel Corp., CA, U.S.A.).

\section{RESULTS}

Body weights. Mean body weights were similar among groups at $1 \mathrm{~d}$ of age $(6.7 \pm 0.1,6.6 \pm 0.1$, and $6.8 \pm 0.1 \mathrm{~g}$ for groups $\mathrm{L}, \mathrm{M}$, and $\mathrm{S}$, respectively). Rearing rats in different litter sizes significantly changed their growth rates, so that those suckled in large litters had the lowest body weights and those suckled in small litters had the highest body weights at weaning. Mean body weights at weaning were $38.6 \pm 0.9$, $52.8 \pm 1.7$, and $60.1 \pm 1.3 \mathrm{~g}$ for groups $\mathrm{L}, \mathrm{M}$, and $\mathrm{S}$, respectively, and they were significantly different from each other. The differences in body weights were still apparent at 12 wk of age after the rats were weaned to a rat chow diet $a d$ libitum. However, only rats in group L $(410.0 \pm 14.6 \mathrm{~g})$ were significantly lighter than those in the other two groups. There was no difference in the mean body weights between groups $\mathrm{M}$ and $\mathrm{S}$, although the mean body weight $(497.6 \pm 9.8 \mathrm{~g})$ in group $\mathrm{S}$ tended to be higher than in group $\mathrm{M}(485.6 \pm 6.4 \mathrm{~g})$.

Food intake. Food intake (g/pup/d) of pups in all groups increased with age. However, the intake of pups in group L was significantly lower than in group $\mathrm{S}$ between the time of weaning and $60 \mathrm{~d}$ of age, after which there were no differences in food intake among groups. However, when the amount of food eaten was calculated on a body weight basis (g/g body wt/d), there were no differences in food intake among groups from weaning to $12 \mathrm{wk}$ of age. The amount of food intake on a $\mathrm{g} / \mathrm{g}$ body $w \mathrm{t} / \mathrm{d}$ basis decreased with age from $0.147 \pm 0.011$, $0.149 \pm 0.013$, and $0.145 \pm 0.007$ at $\mathrm{d} 30$ for groups $\mathrm{L}, \mathrm{M}$, and $\mathrm{S}$, respectively, to $0.069 \pm 0.006,0.059 \pm 0.003$, and $0.062 \pm$ 0.007 at 12 wk for groups L, M, and S, respectively.

Tissue fat content. Rearing pups in different litter sizes significantly alters their fat contents in the fat pads (Fig. 1A) and carcasses (Fig. $1 B$ ) both at the time of weaning and at 12 wk of age, with those in group L having the lowest and those in group $\mathrm{S}$ having the highest fat content $(p<0.05)$. Although pups reared in group $\mathrm{L}$ had significantly lower fat content in both the fat pads and carcass than those in group $\mathrm{M}$ at weaning, they were not significantly different at $12 \mathrm{wk}$ of age, although those in group L tended to be lower than those in group M.
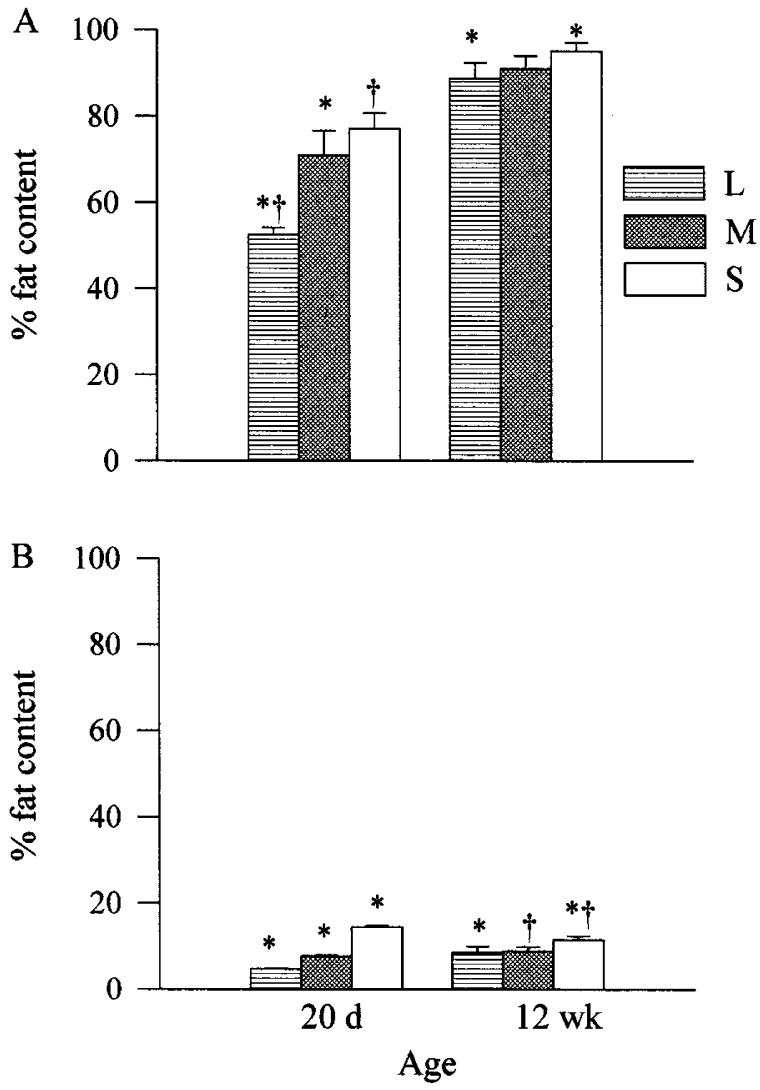

Figure 1. Fat content of fat pads $(A)$ and carcass $(B)$ at $20 \mathrm{~d}$ and $12 \mathrm{wk}$. Values are mean $\pm \mathrm{SD}, n=8$ litters per group. ${ }^{*} \dagger$ Significantly different at age, $p<0.05$.

Insulin response and glucose response to an oral glucose load. Basal plasma insulin levels were significantly different among groups at $20 \mathrm{~d}$, with group $\mathrm{L}$ having the lowest and group $\mathrm{S}$ the highest insulin levels $(p<0.05$, Fig. $2 A)$. The insulin levels in group $\mathrm{L}$ remained lower than those in the other two groups at all time points after an oral load of glucose, so that the 60-min total insulin response, calculated from the area under the curve, was significantly lower $(p<0.05)$ in group L than in the other two groups. They were 19,825 $\pm 2,028$, $25,380 \pm 1,388$, and $25,661 \pm 1,215 \mathrm{pmol} \cdot \mathrm{L}^{-1} \cdot \mathrm{h}^{-1}$ for groups $\mathrm{L}, \mathrm{M}$, and $\mathrm{S}$, respectively. At $12 \mathrm{wk}$ of age, there were no significant differences among groups in the basal and postglucose insulin levels and in the total plasma insulin levels over the 60-min period (Fig. 2B). Sixty-minute total insulin responses were $28,384 \pm 1,786$ for group L, 28,375 $\pm 2,885$ for group $\mathrm{M}$, and $28,706 \pm 1,671 \mathrm{pmol} \cdot \mathrm{L}^{-1} \cdot \mathrm{h}^{-1}$ for group $\mathrm{S}$.

Mean basal glucose level was highest in group $\mathrm{S}$ at $\mathrm{d} 20$ despite its higher basal plasma insulin level ( $p<0.05$, Fig. $3 A)$ than the other two groups. Total plasma glucose level, calculated from the area under the curve, over the 60 -min period after the glucose load was also highest in group $S(620 \pm 46$, $691 \pm 48$, and $792 \pm 34 \mathrm{mmol} / \mathrm{h}$ for groups L, M, and S, respectively) $(p<0.05)$. There were no significant differences among groups at $12 \mathrm{wk}(530 \pm 26 \mathrm{mmol} / \mathrm{h}$ for group L, $537 \pm$ 28 for group M, and $562 \pm 27$ for group S) (Fig. $3 B$ ).

Adipose tissue FAS and lipogenic activities. Basal and postglucose FAS activities at $12 \mathrm{wk}$ of age were higher than 

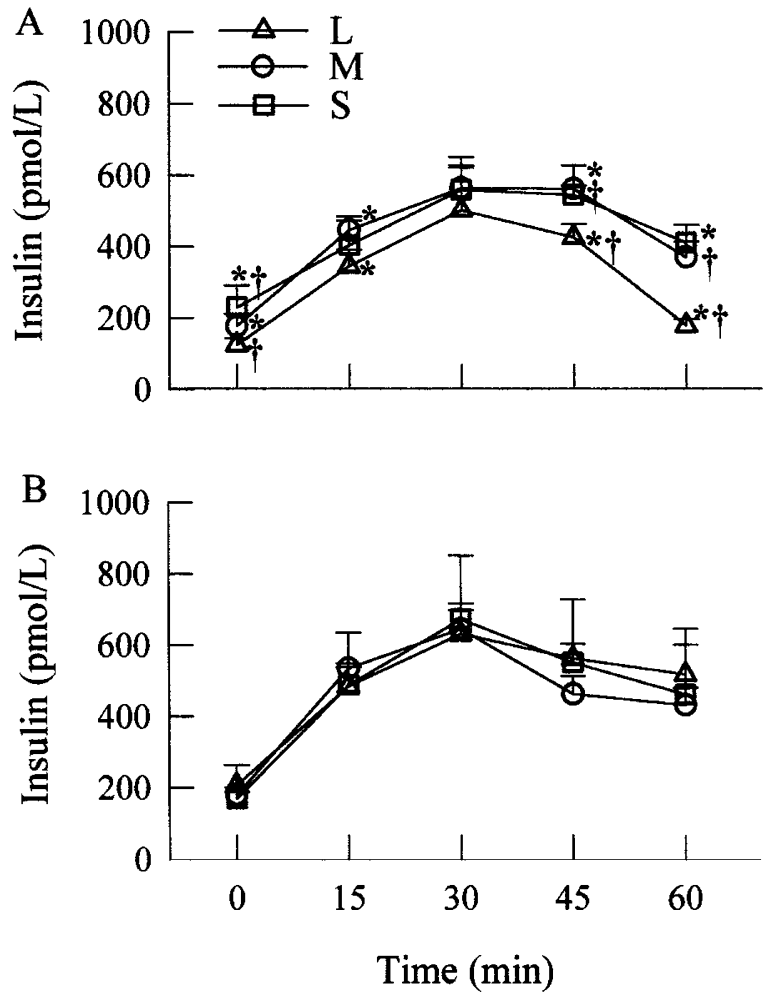

Figure 2. Basal and postglucose load plasma insulin levels at $20 \mathrm{~d}(A)$ and 12 wk $(B)$. Values are mean $\pm \mathrm{SD}, n=8$ litters per group. $* \dagger$ Significantly different at same time point, $p<0.05$.

those during the suckling period for all groups. Basal FAS activity was lowest in group $\mathrm{L}$ and highest in group $\mathrm{S}(p<$ 0.05 ) at age $20 \mathrm{~d}$ (Fig. $4 A$ ) and $12 \mathrm{wk}$ (Fig. $4 B$ ). Sixty-minute postglucose FAS activity was also highest in group $\mathrm{S}$ at $20 \mathrm{~d}$ $(p<0.05)$, but at $12 \mathrm{wk}$, although the FAS activity was still highest, it was not significantly different from group M.

Basal lipogenic activities in the fat pads and lipogenic activities $60 \mathrm{~min}$ after a glucose load were significantly different among groups at age $20 \mathrm{~d}(p<0.05$, Fig. $5 A)$ with pups in group L having the lowest and pups in group $\mathrm{S}$ having the highest activities. At $12 \mathrm{wk}$ of age, basal and postglucose activities remained significantly higher $(p<0.05)$ in group $\mathrm{S}$ (Fig. 5B).

\section{DISCUSSION}

Results from our study show that excess milk intake during suckling can cause a decrease whereas deficient milk intake can cause an increase in glucose tolerance at weaning. These effects are only temporary, as after weaning these rats to standard chow ad libitum, the differences in glucose and insulin curves after glucose loading are no longer apparent among groups at age $12 \mathrm{wk}$, suggesting that nutrition during the suckling period has no long-term adverse effects on insulin secretion or glucose tolerance. Our study is at odds with those of other investigators who have shown that undernutrition or overnutrition during the early neonatal period predisposes an individual to the development of diabetes mellitus, impaired glucose tolerance, and/or obesity in adulthood. Swenne et al. (18) have reported that rats that were protein-calorie restricted
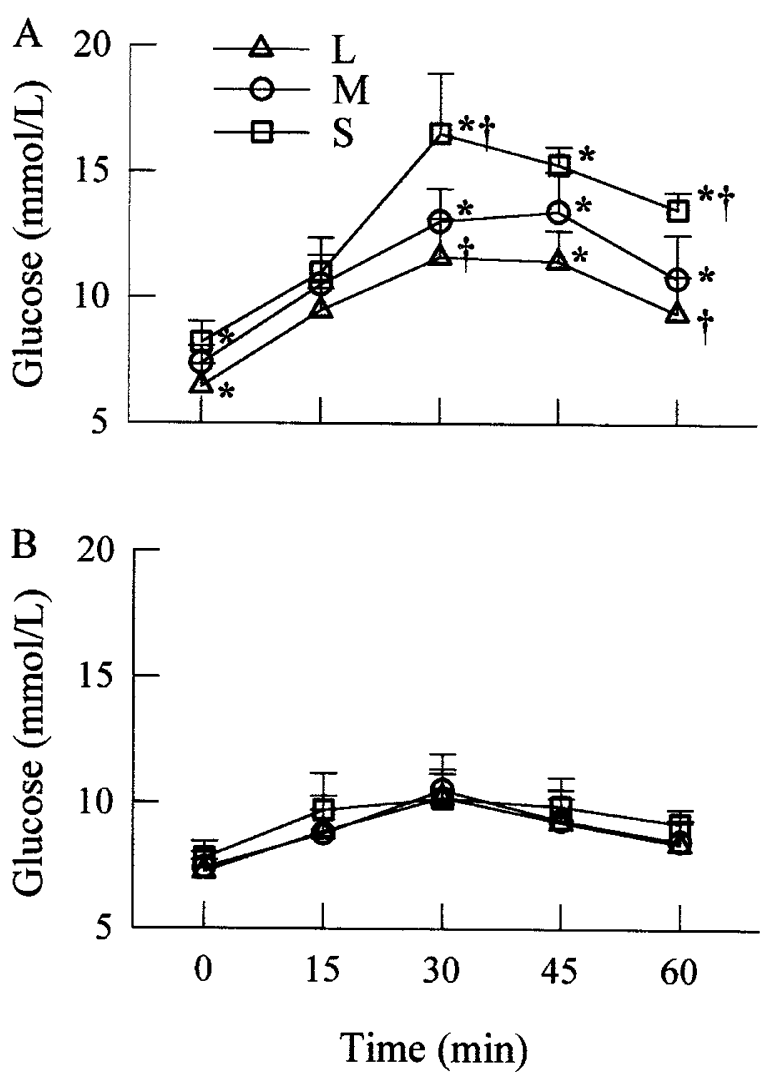

Figure 3. Basal and postglucose load plasma glucose levels at $20 \mathrm{~d}(A)$ and $12 \mathrm{wk}(B)$. Values are mean $\pm \mathrm{SD}, n=8$ litters per group. ${ }^{*} \dagger$ Significantly different at same time point, $p<0.05$.

at the early postweaned periods are predisposed to diabetes mellitus in adulthood because of a permanent reduction in the number of pancreatic islet $\beta$ cells. This suggests that nutrient availability during early life affects cellular proliferation, leading to permanent changes in islet cell numbers, an observation supporting the concept of a "critical" period of growth proposed by Knittle and Hirsch (19). However, histopathologic studies of children dying from kwashiorkor have shown no association between protein-calorie malnutrition and pancreatic islet cell numbers. Histologic sections from these children have demonstrated normal, hyperplastic, or atrophic changes in pancreatic islet cells. The association between early malnutrition and diabetes is at odds with the findings of You et al. (20) who have shown that overnutrition during early infancy can increase the propensity to develop diabetes mellitus and impaired glucose tolerance in adulthood. Therefore, mechanisms other than changes in $\beta$-cell population may be the cause of a permanent alteration in glucose metabolism. Leahy et al. (21) have reported that prolonged exposure to high levels of glucose can induce defects in insulin secretion by pancreatic $\beta$ cells, a condition often seen in overnutrition. This defect in insulin secretion is attributed to a decrease in sensitivity of $\beta$ cells to glucose stimulation, possibly due to either a down-regulation of Glut-2 transporter (22) or a reduction in glucokinase activity (23). These postulated causes imply that early nutrition can cause programming of metabolic patterns through permanent alterations in enzyme activities and/or expressions of genes involved in metabolic processes. 

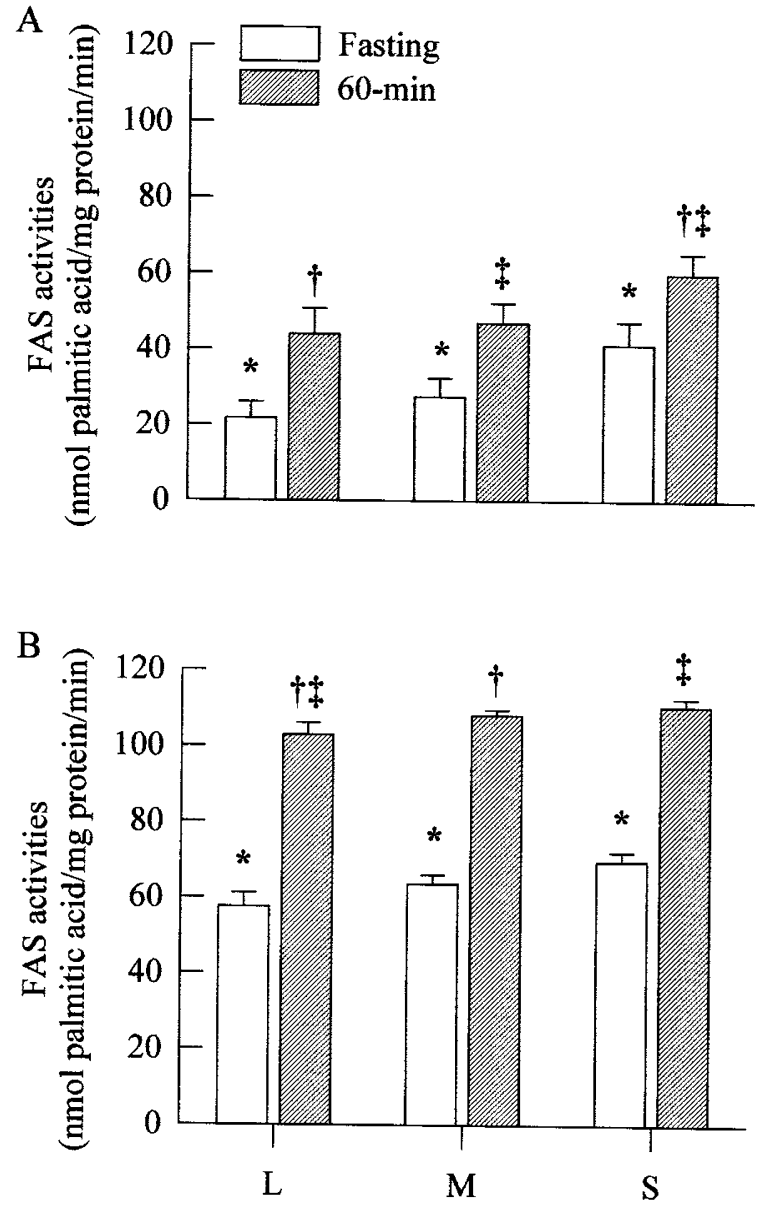

Figure 4. Basal and postglucose retroperitoneal fat pad FAS activities at $20 \mathrm{~d}$ $(A)$ and $12 \mathrm{wk}(B)$. Values are mean $\pm \mathrm{SD} ; n=8$ litters per group. $* \dagger$ Significantly different at same age, $p<0.05$.

The observed differences in glucose tolerance between our findings and those of other investigators probably stem from differences in the age of rats studied and the degree of malnutrition sustained by the rats (18). Underfeeding at birth was induced in our study by raising newborn pups in large litters, whereas undernutrition in the study of Swenne et al. (18) was induced by weaning 3 -wk-old pups to a diet containing $5 \%$ protein for a duration of $3 \mathrm{wk}$. Their study design resulted in a food intake of approximately 60 to $65 \%$ in the low-protein diet group compared with controls, whereas milk intake in our large litter group was approximately $27 \%$ lower than those of controls (unpublished data). It can be inferred that the degree of malnutrition induced in our study was not severe enough to cause any damage to the pancreatic $\beta$ cells, thus accounting for the lack of impairment in glucose tolerance at $12 \mathrm{wk}$ of age. Furthermore, the timing of nutritional insult also plays an important role in determining the future outcome of glucose tolerance. Martin et al. (24) have reported that rats that were undernourished starting at weaning had a poorer glucose tolerance at $70 \mathrm{~d}$ of age compared with rats that were undernourished at an earlier age. Their study suggests that the earlier the exposure, the better can the pancreas adapt functionally to the unfavorable nutritional environment, and that this adaptation can be mediated by altered glucose transport or metabolism in
A

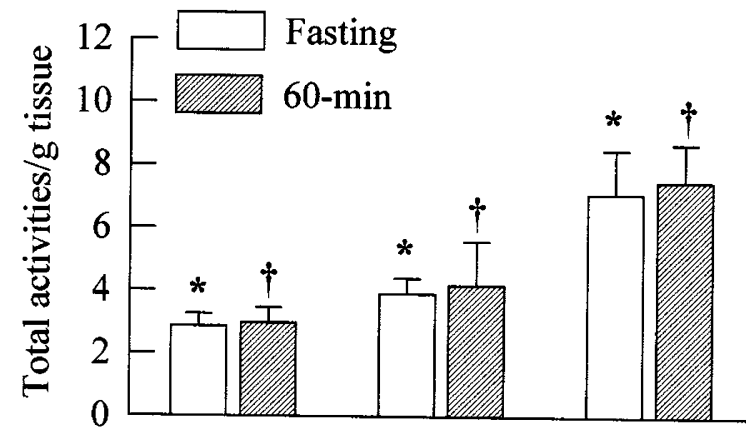

B

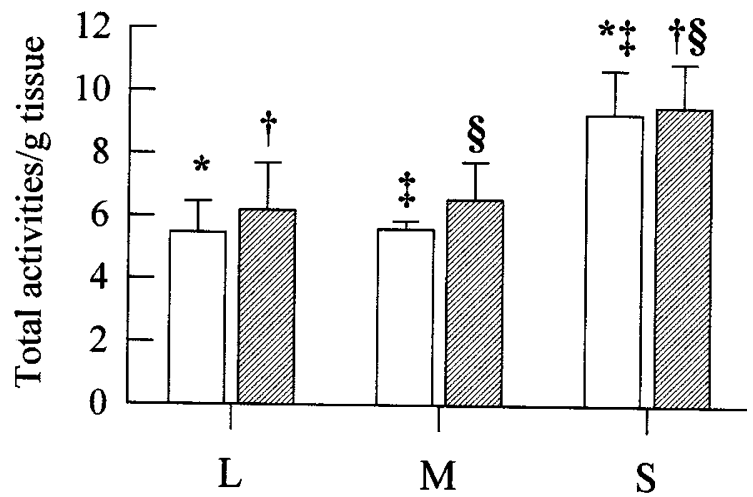

Figure 5. Basal and postglucose load retroperitoneal fat pads lipogenic activities at $20 \mathrm{~d}(A)$ and $12 \mathrm{wk}(B)$. Values are mean $\pm \mathrm{SD}, n=8$ litters per group. $*+\$$ Significantly different at same age, $p<0.05$.

the $\beta$ cells. Thus, changes in insulin response to glucose are dependent not only on dietary factors but also on the age when the animals are exposed to nutritional insult.

We found that although insulin and glucose tolerance in adult rats is not affected by early nutritional perturbation, FAS and lipogenic activities in the adipose tissues are significantly affected. The persistently higher FAS activities and lipogenic activities in the fat pads of adult rats suckled in small litters suggest that overnutrition during suckling imparts a permanent effect in adipose tissue enzyme activity, resulting in larger fat pads in these animals. This finding is supported by epidemiologic studies that report that fatter infants have a greater propensity than thinner infants for becoming fat adults $(25,26)$. Early studies using rats have shown that the increase in adult body fat content due to overnutrition in infancy is due to an increase in body fat cell number (19). Contrary to this finding of adipocyte hyperplasia in rats, studies in baboons overfed in infancy show that the increase in adult body fat is due largely to adipocyte hypertrophy (27), an observation supported by findings in piglets (28). Therefore, early programming of body composition may not be due solely to an alteration in cell number but in cellular metabolic activities as well. Insulin is known to stimulate lipogenesis by promoting mRNA expression of lipogenic enzymes (29). The high insulin levels at weaning in rat pups suckled in small litters could cause the higher FAS and lipogenic activities in the adipose tissues, leading to an enhancement in the lipogenic gene expression and lipogenic activities in the adipocytes. Even though the 
effects of early nutrition on insulin and glucose responses are no longer apparent in the adult, the changes in FAS and lipogenic activities imposed by insulin during suckling persist in adulthood. Thus, the enhanced adipose tissue FAS and lipogenic activities are independent of insulin responses in adulthood, suggesting that early metabolic programming by insulin appears to be responsible for the permanent changes in the enzymes in the fat synthetic pathways.

In conclusion, data from this study suggest that manipulation of milk intake during suckling imposes changes in insulin and glucose tolerance at weaning, but the effects are only temporary and are not observed in adults. However, higher milk intake during suckling imparts an enhancement of FAS and lipogenic activities in the adipose tissue, and these changes persist into adulthood, thus increasing the propensity for the development of obesity.

Acknowledgments. The authors thank Y.M. Lo and the staff at the Laboratory Animal Unit for their technical help.

\section{REFERENCES}

1. Milner RDG 1971 Metabolic and hormonal responses to glucose and glucagon in patients with infantile malnutrition. Pediatr Res 5:33-39

2. Weinkove C, Weinkove EA, Pimstone BL 1976 Glucose tolerance and insulin release in malnourished rats. Clin Sci Mol Med 50:153-163

3. Crace CJ, Swenne I, Milner RDG 1989 Long-term follow-up after early proteincalorie malnutrition in young rats: sex difference in glucose tolerance and serum insulin levels. Metabolism 38:933-938

4. Plagemann A, Heidrich I, Gotz F, Rohde W, Dorner G 1992 Obesity and enhanced diabetes and cardiovascular risk in adult rats due to early postnatal overfeeding. Exp Clin Endocrinol 99:154-158

5. Salans LB, Knittle JL, Hirsch J 1968 The role of adipose cell size and adipose tissue insulin sensitivity in the carbohydrate intolerance of human obesity. J Clin Invest 47:153-165

6. Bjorntorp P, Berchtold P, Tibblin G 1971 Insulin secretion in relation to adipose tissue in men. Diabetes 20:65-70

7. Wang D, Sul HS 1995 Upstream stimulatory factors bind to insulin response sequence of the fatty acid synthase promoter. J Biol Chem 270:28716-28722

8. Moustaid N, Jones BH, Taylor JW 1996 Insulin increases lipogenic enzyme activity in human adipocytes in primary culture. J Nutr 126:865-870

9. Cheema SK, Clandinin T 1996 Diet fat alters expression of genes for enzymes of lipogenesis in lean and obese mice. Biochim Biophys Acta 1299:284-288
10. Coupe C, Perdereau C, Ferre P, Hitier Y, Narkewicz M, Girard J 1990 Lipogenic enzyme activities and mRNA in rat adipose tissue at weaning. Am J Physio 258:E126-E133

11. Clarke SD 1993 Regulation of fatty acid synthase gene expression: an approach for reducing fat accumulation. J Anim Sci 71:1957-1965

12. West DB, Diaz J, Roddy S, Woods SC 1987 Long-term effects on adiposity after preweaning nutritional manipulations in the gastrostomy-reared rat. J Nutr 117:12591264

13. Fain JN, Wilhelmi AE 1962 Effects of adrenalectomy, hypophysectomy, growth hormone, and thyroxine on fatty acid synthesis in vivo. Endocrinology 71:541-547

14. Sheng HP, Huggins R, Garza C 1982 Chemical maturation in growing guinea pigs. Am J Physiol 242:R390-R393

15. Nepokroeff CM, Lakshamanan MR, Porter JW 1975 Fatty-acid synthase from rat liver. Methods Enzymol 35:37-44

16. Jungas RL 1968 Fatty acid synthesis in adipose tissue incubated in tritiated water. Biochemistry 7:3708-3717

17. Fain JN, Scow RO 1966 Fatty acid synthesis in vivo in maternal and fetal tissues in the rat. Am J Physiol 210:19-25

18. Swenne I, Borg LAH, Crace CJ, Schnell-Landström A 1992 Persistent reduction of pancreatic beta-cell mass after a limited period of protein-energy malnutrition in the young rat. Diabetologia 35:939-945

19. Knittle JL, Hirsch J 1968 Effect of early nutrition on the development of rat epididymal fat pads: cellularity and metabolism. J Clin Invest 47:2091-2098

20. You S, Götz F, Rohde W, Dörner G 1990 Early postnatal overfeeding and diabetes susceptibility. Exp Clin Endocrinol 96:301-306

21. Leahy JL, Cooper HE, Deal DA, Weir GC 1986 Chronic hyperglycemia is associated with impaired glucose influence on insulin secretion. A study in normal rats using chronic in vivo glucose infusions. J Clin Invest 77:908-915

22. Purrello F, Buscema M, Vetri M, Vinci C, Gatta C, Forte F, Rabuazzo AM, Vigneri R 1991 Glucose regulates both glucose transport and the glucose transporter gene expression in a hamster-derived pancreatic beta-cell line. Diabetologia 34:366-369

23. Liang Y, Najafi H, Smith RM, Zimmerman EC, Magnuson MA, Tal M, Matchinsky FM 1992 Concordant glucose induction of glucokinase, glucose usage, and glucosestimulated insulin release in pancreatic islets maintained in organ culture. Diabetes 41:792-806

24. Martin MA, Alvarez C, Goya L, Portha B, Pascual-Leone M 1997 Insulin secretion in adult rats that had experienced different underfeeding patterns during their development. Am J Physiol 272:E634-E640

25. Agras WS, Kraemer HC, Berkowitz RI, Korner AF, Hammer LD 1987 Does a vigorous feeding style influence early development of obesity? J Paediatr 110:799804

26. Dietz WH 1994 Critical periods in childhood for the development of obesity. Am J Clin Nutr 59:955-959

27. Lewis DS, Bertrand HA, McMahan CA, McGill Jr HC, Carey KD, Masoro EJ 1989 Influence of preweaning food intake on body composition of young adult baboons. Am J Physiol 257:R1128-R1135

28. Mørkerberg JC, Sheng HP, Mersmann HJ 1992 Differences in energy intake affect body composition and adipose tissue accretion in young growing piglets. Nutr Res $12: 1503-1516$

29. Paulauskis JD, Sul HS 1989 Hormonal regulation of fatty acid synthase gene transcription in liver. J Biol Chem 264:574-579 